\title{
Cucumber mosaic virus resistance and reproductive biology of brazilian melon accessions
}

\author{
Nadia Carolina Sanabria-Verón ${ }^{1}$, Cláusio Antônio Ferreira de Melo $^{2}$, Jadergudson Pereira ${ }^{3}$, \\ Glauber Henrique de Sousa Nunes ${ }^{4}$, Ohana Luiza Santos de Oliveira ${ }^{5}$, Ronan Xavier Corrêa ${ }^{6}$
}

\begin{abstract}
In melon (Cucumis melo) the resistance to Cucumber Mosaic Virus (CMV) and the knowledge about reproductive characteristics are important for selection of genitors for breeding population. So, the objective was to investigate if different accessions of melon from a Brazilian germplasm bank have variability in resistance to CMV (FNY strain) and polymorphism in resistance loci markers, as well as whether there is genetic diversity on resistance and floral morphology descriptors and reproductive biology, aiming at genetic improvement. The symptoms induced by CMV were evaluated in 52 melon genotypes which were genotyped with three markers of single nucleotide polymorphisms related to CMV resistance. A sample of 24 genotypes was characterized for floral and reproductive descriptors. The significant variation in resistance levels allows classifying the accessions in five groups. The polymorphisms detected by the markers were independently distributed in these groups, consistent with the oligogenic quantitative expression of the melon's resistance. There were significant differences between accessions in floral and reproductive descriptors. Through the Ward-MLM multivariate strategy, these accesses were distributed into seven groups with distinct reproductive characteristics, including variability in pollen viability. Therefore, there are Brazilian accessions of melon that have resistance to $\mathrm{CMV}$, as well as variability in reproductive characteristics.
\end{abstract}

Index terms: molecular marker, SNP-CAP, genetic diversity, floral and reproductive variability, WardMLM, $C M V$.

\section{Resistência ao Cucumber mosaic virus e biologia reprodutiva de acessos brasileiros de meloeiro}

Corresponding author: ronanxc@uesc.br

Received: March 05, 2019 Accepted: June 03, 2019

Copyright: All the contents of this journal, except where otherwise noted, is licensed under a Creative Commons Attribution License.

\begin{abstract}
Resumo - No meloeiro (Cucumis melo), a resistência ao Cucumber mosaic virus (CMV) e o conhecimento sobre características reprodutivas são importantes para escolha de genitores de populações de melhoramento. Desta forma, objetivou-se verificar se diferentes acessos de meloeiro em um banco de germoplasma brasileiro possuem resistência ao CMV (estirpe FNY) e polimorfismo, em locos marcadores de resistência, bem como se há diversidade genética quanto à resistência e aos descritores florais e reprodutivos, visando ao melhoramento genético. Os sintomas ocasionados por CMV foram avaliados em 52 genótipos de meloeiro, os quais foram genotipados com três marcadores de polimorfismos de nucleotídeos únicos, relacionados com resistência ao CMV. Uma amostra de 24 genótipos foi caracterizada quanto a descritores florais e reprodutivos. A variação significativa nos níveis de resistência possibilitou classificar os acessos em cinco grupos. Os polimorfismos detectados por meio dos marcadores distribuíramse de forma independente nesses grupos, consistente com a natureza quantitativa oligogênica da resistência. Houve diferenças significativas entre acessos nos descritores florais e reprodutivos. Por meio da estratégia multivariada Ward-MLM, esses acessos distribuíram-se em sete grupos com características reprodutivas distintas, incluindo-se variabilidade em viabilidade polínica. Portanto, há acessos brasileiros de meloeiro que possuem resistência ao CMV, bem como variabilidade nas características reprodutivas.
\end{abstract}

Termos para indexação: marcador molecular, SNP-CAP, diversidade genética, variabilidade floral e reprodutiva, Ward-MLM, CMV.

${ }^{1} \mathrm{PhD}$ Student in Vegetal Production, State University of Santa Cruz (UESC), Ilhéus, BA, Brazil. E-mail: nadia_sanave@hotmail.com ${ }^{\text {(ORCID }}$ 0000-0003-0316-349x)

${ }^{2} \mathrm{PhD}$ Professor in Agrarian and Environmental Science Department, State University of Santa Cruz (UESC), Ilhéus-BA, Brazil. E-mail: clausiomelo@gmail.com (ORCID 0000-0001-9007-1731)

${ }^{3} \mathrm{PhD}$ Professor in Agrarian and Environmental Science Department, State University of Santa Cruz (UESC), Ilhéus-BA, Brazil. E-mail: jader@uesc.br(ORCID 0000-0001-9934-1734)

${ }^{4}$ PhD Professor in Vegetal Sciences Department, Federal University of Semi-Arid (UFERSA), Mossoró-RN, Brazil. E-mail: glauber@ufersa. edu.br (ORCID 0000-0002-7189-2283)

${ }^{5} \mathrm{PhD}$ Student in Biotechnology, Health Science Institute in Federal University of Bahia (UFBA), Salvador-BA, Brazil. E-mail: ohanaluiza@ hotmail.com (ORCID 0000-0003-3414-6537)

${ }^{6} \mathrm{PhD}$ Professor in Biological Science Department, State University of Santa Cruz (UESC), Ilhéus-BA, Brazil. E-mail: ronanxc@uesc.br ${ }^{\text {(ORCid }}$ 0000-0002-4010-1565) 


\section{Introduction}

Melon (Cucumis melo L.) is a tropical crop of high commercial value, originating from central Asia and Africa, with its greatest botanical diversity found in India, Iran, Afghanistan and China. Additionally, Brazil has a large sample of germplasm variability, with varieties and unique cultivars, conserved and produced by local producers. (ROCHA et al., 2010; CASTILHOS, 2012; COSTA, 2012). Much of the diversity of the C. melo Brazilian germplasm is conserved in the Cucurbitaceae germplasm bank of the Federal University of Semiarid (UFERSA), culture productive region in Brazil (DANTAS et al., 2012; ARAGÃO et al., 2013).

Cucumber mosaic virus (CMV) belongs to the Bromoviridae family, genus Cucumovirus, and is highly destructive and reported to infect more than 1,200 plant species worldwide (MORRONI et al., 2008; DUBEY et al., 2015). The main symptoms induced by the virus are mosaics, leaf distortion, plant discoloration and yellowing, which are associated with large yield losses in melon plants. The phenotypic response of melons to $\mathrm{CMV}$ inoculation has been evaluated at different number of days after inoculation, providing the establishment of a numerical rating scale (PALUKAITIS, 1992; ESSAFI et al., 2009; GUIU-ARAGONÉS et al., 2014). Symptom scores range from 0 to 5 , with a score of 0 showing no symptoms; score 1, with very light mosaic only on the first one or two leaves; score 2, light mosaic on all leaves; score 3 , stronger mosaic on all leaves; score 4 , very strong mosaic with some wavy leaves; score 5 , very strong mosaic with wavy and very small leaves and small plants.

In a resistance study it was shown that the wild Korean accession PI161375 ('Sonwang Charmi' - SC) has oligogenic resistance to $\mathrm{CMV}$, being recessive and quantitative, with QTL located in the linking groups GLIII, GLV and GLXII. A collection of near isogenic lines (NIL) has been developed to characterize CMV resistance levels from the initial cross between SC and the susceptible variety 'Pele de Sapo' (PS), followed by haploidization, reciprocal crosses and monitored selections with molecular markers (EDUARDO et al., 2005). Subsequently, specificities of NILs for different CMV viral strains were confirmed (ESSAFI et al., 2009; GINER et al., 2017). A more detailed mapping of this region showed the $c m v 1$ resistance gene in a $2.2 \mathrm{cM}$ area located on the GLXII. In addition, $c m v 1$ confers total resistance to some CMV strains, indicating that in these cases the resistance is not quantitative and that $c m v l$ is sufficient to confer total resistance to these CMV strains. However, in cultivar SC to CMV resistance is proposed as oligogenic, where different loci confer resistance to different CMV strains, but not necessarily quantitative, since at least one of these genes ( $\mathrm{cmv}$ l) confers total resistance, similar to SC parental, and do not need contribution from other loci
(ESSAFI et al., 2009). Subsequent studies have shown that the resistance of this melon cultivar to CMV is governed by one gene (of greater effect) and at least two QTL among the other three melon genomic regions involved in CMV resistance. Therefore, working as qualitative in certain crossings and as quantitative in other crossings (GUIUARAGONÉS et al., 2014).

Melon genotypes have different morphological and biochemical characteristics and wide DNA polymorphic divergence due to their origin, and can be grouped into African, Spanish, European and North American botanical varieties. Morphological characteristics related to the vegetative and flowering stages are parameters that allow maintaining the germplasm population structure for commercial activities and breeding programs (STEPANSKY et al., 1999; STAUB et al., 2004). As for sexual expression, accessions are classified as monoecious, that is, male and female flowering plants on the same plant, but separated along the branch, as well as andromonoic, that is, with male and hermaphrodite flowering plants separated on the same plant. (TORRES FILHO et al., 2009). Melon flowers require entomophilic pollination to reach a large number of formed fruits, and both manual cross pollination and open pollination by honey bees introduced into the cultivated area can ensure adequate levels of crop pollination. (SOUSA et al., 2009). The production of male flowers occurs for approximately 30 days, starting around 14 to 15 days after planting, while hermaphrodite flowers are produced from 20 days after transplantation over a period of 15 days (ABREU et al., 2008).

Despite the wide genetic and morphological diversity in the Brazilian collections of C. melo, knowledge of the variability of disease resistance response has been little explored. Farther, the understanding of reproductive relationships between accessions is scarce, which hampers strategies for genetic improvement, especially involving crosses between accessions and varieties. Thus, this study was carried out to verify if different melon accessions in a Brazilian germplasm bank have variability in CMV resistance (FNY strain) and polymorphism in resistance marker loci, as well as whether there is genetic diversity regarding to resistance and floral morphology descriptors and reproductive behavior, aiming at genetic improvement.

\section{Material and Methods}

Plant Material - The plant material used in this study was obtained from the Cucurbitaceae Germplasm Bank of the Federal University of Semiarid (UFERSA), consisting of 42 traditional Brazilian accessions, four intervarietal hybrids, two commercial cultivars and two known contrasting varieties for CMV resistance. One seed was sown in each container containing $0.5 \mathrm{~L}$ of previously autoclaved soil and fertilized substrate, with 10 replicates 
per variety.

Throughout the experiment (about 30 days), the seedlings were kept in a growth chamber with $80 \%$ relative humidity, with a photoperiod of photoperiod of $13 \mathrm{~h}$ light at $18^{\circ} \mathrm{C}$ during the night and $24^{\circ} \mathrm{C}$ during the day. These same conditions were used to produce squash (Cucurbita pepo L.) seedlings, which was used for reactivation and multiplication of CMV.

Inoculations with CMV and Symptom Assessment

- CMV resistance analysis was performed by artificial inoculation on cotyledonary leaf, lightly dusted with abrasive agent and wetted with the viral suspension, followed by very light friction with a porcelain stick. The design used for the experiment was completely randomized under controlled experimental conditions in plant growth chamber.

FNY strain, previously characterized (MOCHIZUKI and OHKI, 2012), was chosen because it induces contrasting CMV resistance symptoms in the two accessions used as control: PI161375 'Sonwang Charmi' - SC, hereafter referred to as PI, resistance standard; 'Pele de Sapo', PS (GUIU-ARAGONÉS et al., 2014). Leaves of Cucurbita pepo (Zucchini Caserta TS) infected by CMV, also under controlled conditions, were used for inoculum production by maceration in phosphate buffer $[(0.03 \mathrm{~mol} / \mathrm{L}$ $\mathrm{Na}_{2} \mathrm{HPO}_{4}, 0.2 \%$ diethyldithiocarbamate (DIECA), in 1:4 weight/volume ratio (leaf:buffer)] (LECOQ et al., 1991). An aliquot of leaf extract was applied to each expanded cotyledonary leaf of the treatments (about seven to nine days after sowing). Symptom assessments were performed using a numerical scale rewritten by GUIU-ARAGONÉS et al. (2014), repeating assessments at 7, 14 and 21 days after inoculation (DAI) to represent initial symptoms at seven days and typical disease symptoms at 14 and 21 DAI.

Genetic polymorphism in genomic regions for CMV resistance - The analysis of genomic polymorphism associated with CMV resistance was performed by genotyping with single nucleotide polymorphism markers detected by the PCR amplified product cleavage technique, calling the generated markers SNP-CAP. Thus, the loci analyzed were AI_33-H11 (DELEU et al., 2009), PS_40-E11 (DELEU et al., 2009) and CmeIF4E (MORENO et al., 2008), which were chosen because they represent three QTL responsible for CMV resistance (ESSAFI et al., 2009).

The genomic DNA of the 52 accessions was extracted from leaves macerated in liquid nitrogen, mixed with 2\% CTAB buffer (DOYLE and DOYLE, 1990), modified from protocols previously established for other plants (CORRÊA et al., 1999). The quantification and the integrity analysis of the extracted DNA were performed by $1 \%$ agarose gel electrophoresis with SYBR Safe DNA dye
(Invitrogen ${ }^{\mathrm{TM}}$ ), comparing with the Lambda concentration marker, following DNA dilution to the concentration of $5 \mathrm{ng} / \mu \mathrm{L}$.

Polymerase chain reactions amplification (PCR) were performed for a final volume of $25 \mu \mathrm{L}$ with the addition of: 15ng of genomic DNA, buffer for PCR 1X (Tris- $\mathrm{HCl}$ at $10 \mathrm{mMol} \cdot \mathrm{L}^{-1}, \mathrm{KCl}$ at $50 \mathrm{mMol}^{-1} \mathrm{~L}^{-1} \mathrm{MgCl}_{2}$ at 2 mMol.L $L^{-1}, \mathrm{pH}$ 8.5), TBT-PAR [trehalose at $750 \mathrm{mMol}^{-\mathrm{L}^{-1}}$; BSA at $1 \mathrm{mg} / \mathrm{mL}$; Tween-20 at $1 \%$ ] (SAMARAKOON et al., 2013), dNTPs at $250 \mu \mathrm{Mol} . \mathrm{L}^{-1}$, primer at $0.2 \mu \mathrm{Mol} . \mathrm{L}^{-1}$ (DELEU et al., 2009; MORENO et al., 2008), 1.5 U of Taq DNA polymerase (Invitrogen ${ }^{\mathrm{TM}}$ ). Amplifications were performed in a Veriti ${ }^{\circledR}$ thermal cycler (Applied Biosystems) programmed for the following protocol: initial denaturation at $94{ }^{\circ} \mathrm{C}$ for $2 \mathrm{~min}$, followed by 30 cycles of $94{ }^{\circ} \mathrm{C}$ for $20 \mathrm{~s}, 55^{\circ} \mathrm{C}$ for $20 \mathrm{~s}$ and $72{ }^{\circ} \mathrm{C}$ for 2 min; final extension was performed at $72{ }^{\circ} \mathrm{C}$ for $5 \mathrm{~min}$. SNP-CAP loci amplification products were visualized on $1.8 \%$ agarose gel containing $\mathrm{SYBR}^{\circledR}$ Safe DNA dye (Invitrogen ${ }^{\mathrm{TM}}$ ) and Ladder $100 \mathrm{bp}$ molecular weight marker (Synapse Biotechnology).

Detection of the polymorphism was verified by $3 \%$ agarose gel electrophoresis of PCR products previously digested with specific restriction enzyme: AI_33-H11 loci with Hind III enzyme; loci AI_14-F04, Alu I; and loci CmeIF4E, AfaI (RsaI). The total of $10 \mu \mathrm{L}$ of PCR product plus $2 \mu \mathrm{L}$ of $10 \mathrm{X}$ buffer specific for enzyme and $0.5 \mu \mathrm{L}$ of enzyme were incubated in water bath for 1 hour at $37^{\circ} \mathrm{C}$. The separation of products generated by enzymatic digestion was performed by $3 \%$ agarose gel electrophoresis using SYBR ${ }^{\circledR}$ Safe (Invitrogen ${ }^{\mathrm{TM}}$ ) DNA dye with Ladder 100 bp molecular weight marker (Synapse Biotechnology).

Pollen viability and stigma receptivity - Flowers previously marked the day before were collected at 7 a.m. and placed in petri dishes properly protected with aluminum foil, closed and taken to the laboratory of molecular markers of the Center for Biotechnology and Genetics of the Santa Cruz State University for the performance of essays. The pollen suspension was produced in $50 \mu \mathrm{L}$ of distilled water or saturated sucrose solution by gently pressing the anthers three or four times with the aid of a micropipette tip. Four drops of this suspension were placed at the ends of each petri dish containing the culture medium, where after a predetermined period of time the germination of the pollen grains was evaluated.

For pollen viability evaluation, the morphological staining method was used with Alexander dye to perform a visual classification under the microscope of viable and non-viable grains and to calculate the percentage of viability. Grains with stained nucleus were considered viable, while those that did not showed it were considered dead. For these observations, the Leica 10X microscope 
was used.

In vitro germination of pollen grains was performed in culture medium used by Bruckner et al. (2000). The observation of pollen tube emission was performed with the aid of light microscope, after a certain period, the number of grains that produce viable pollen tube, with length greater than the pollen diameter (SALLES et al., 2006). The number of pollen grains per visual field and the percentage of germinated pollen grains were evaluated. In each drop of suspension, four fields of view under the microscope were analyzed, which is equivalent to four repetitions. Grains whose pollen tubes had exceeded the diameter length of the pollen grain itself were considered germinated. Each flower collected was subjected to two concentrations and observed at a certain time. The experiment was carried out in a completely randomized design with five metric repetitions in each plant for each quantitative descriptor. The significant difference was verified by analysis of variance (ANOVA) using SISVAR software (FERREIRA, 2011). Additionally, the Tukey test at 5\% probability was performed for the reproductive biology variables, as well as the Scott-Knott grouping at $5 \%$ probability, aiming to group the averages distributed among accessions within a variety.

Floral and reproductive genetic diversity - Sowing of the different melon accessions was carried out in January, in polystyrene cups, filled with commercial substrate and soil in a 1:1 ratio. Transplantation was performed 15 days after sowing in a $10 \mathrm{~L}$ polystyrene pot. Fertilization management was done via chemical fertilization and irrigation (CASTRO LIMA et al., 2018).

The measurement of the variables mentioned below was performed with a digital caliper graduated in millimeter. Number of days for flowering: the number of days for the appearance of the first male flower in 50\% of the plants of the plot was counted; Petal length (PL): corresponding to the distance of the two longitudinal ends; Flower width (FW): corresponding to the largest horizontal distance between the edges; Receptacle length (RL): The length of the petal corresponded to the distance of the two longitudinal ends; Bracts length (BL): from the insertion of the bract in the receptacle; Receptacle Width (RW): from the largest dimension of the receptacle diameter; Flower length (FL): corresponding to the distance of the two longitudinal ends.

Beyond the analysis of variance (ANOVA) for quantitative floral descriptors, Ward-MLM multivariate analysis was also performed. The Ward-MLM multivariate procedure was performed using the distance matrix obtained by the logarithmic function of Gower coefficient (Gower, 1971), according to the method proposed by MELO et al. (2015) on SAS Software analysis platform (SAS, 2000). The average values of the quantitative variables were included in the analysis together with the qualitative access data. Additionally, information on symptomatology observed in inoculated plants was added to the analysis by coding for the disease caused by CMV at $21^{\text {st }}$ DAI.

\section{Results and Discussion}

\section{Symptomatology and genetic polymorphism} concerning to CMV resistance -In scale-based evaluation of scores attributed to phenotypic modifications after artificial CMV inoculation, highly significant differences in symptoms were observed between the different DAI numbers. The average score values increased as a result of the increase in the DAI number, which were arranged in seven distinct groups by the mean comparison test (Tukey 5\%; DMS: 0.1419). Regarding the evaluated germplasm, there were significant differences between the different accessions within each observation moment, proving the existence of genetic variability for CMV resistance in these materials. The distribution of scores among the accessions in the $7^{\text {th }}$ DAI showed a high coefficient of variation $(\mathrm{CV}=62 \%)$, and this statistical parameter was reduced at the $14^{\text {th }}$ DAI (54\%) and considerably lower in the $21^{\text {st }}$ DAI (34\%), this last point of observation was adopted for the other analyzes because the symptoms of both controls (PI and PS) were typical of the disease, as described in the literature.

Symptoms phenotypic assessment based on the numerical scale observed at the $21^{\text {st }}$ DAI was consistent for the experimental controls (Table 1). The PI exotic genotype, used as resistance control, showed the lowest score (average 0.3), while the PS cultivar, used as the susceptibility standard, had a high mean symptom score (4.8), with death of some repetitions throughout the experimentation. Regarding the evaluated germplasm, A16 and A42 accessions presented scores lower than 0.5 , in contrast to A43 and A45 accessions which showed the highest values (score 5.0). The PSa x A16 and A16 $\mathrm{x}$ PI hybrids showed average scores of 2.4 and 1.8, respectively.

A wide variation in scores values attributed to symptoms in the tested accessions was observed (Figure 1). The five groups formed by the Scott-Knott test from these scores reveal the existence of different resistance levels of the Brazilian melon accessions to CMV. In group I, formed by plants with resistance levels that did not differ statistically from PI (resistant control), nine accessions and 'Galia' cultivar were included. At the other end of the distribution we find PS cultivar (susceptible standard) along with two accessions that do not differ of it statistically in the intensity of disease symptoms.

Genotyping with SNP-CAP markers located in melon resistance QTL to CMV (ESSAFI et al., 2009; GUIU-ARAGONÉS et al., 2014) explained polymorphisms at these loci among accessions (Table 
1). The PS 40-E11 locus amplified a band of about $390 \mathrm{bp}$ which, after digestion with restriction enzyme, showed distinct alleles between PI and PS (Figure 2). These alleles are present in Brazilian accessions, which have $40 \%$ homozygous genotypes and $60 \%$ heterozygous genotypes. Only five genotypes were homozygous for the allele without the restriction site, which is considered wild (a), representing $10 \%$ of the population analyzed. Mutant allele (b) showed a high population frequency $(0.6)$ with $30 \%$ of genotypes carrying the $\mathrm{G} \rightarrow$ A point mutation in homozygosis. Similar to the previous case, alleles of locus AI_33-H11, generated from the amplicon of about $260 \mathrm{bp}$, were distributed at these same frequencies among the analyzed accessions. However, $28 \%$ of the genotypes were considered homozygous for the wild allele (a), with the restriction site. For the $\mathrm{T} \rightarrow \mathrm{C}$ point mutation allele, the homozygotes for this allele represent $32 \%$ of the population, with a population allele frequency of 0.52 . The CmeIF4E locus linked to the gene $c m v 1$ indicated the presence of only eight genotypes with the same profile as the allelic resistant cultivar PI161375, which has a mutant allele in homozygosis (Table 1). The largest percentage of germplasm analyzed has the allele in its wild based composition, with $55 \%$ of the population in homozygosis.

Pollen viability and stigma receptivity -Staining using Alexander's solution showed typical microscopic pattern demonstrating pollen grain viability (Figure $3 \mathrm{~A})$. The evaluation performed at 8 a.m. showed a significant difference between accessions (Table 2). In this evaluation, A28 accession presented lower viability (117 pollen grains) while A8 accession had the highest value (196.66). For pollen grain viability evaluated at 3 p.m., A28 accession presented lower viability and was statistically different from other accessions. However, greater viability at 3 p.m. was observed in A8 accession (193.33), with an average of 183.08 and a coefficient of variation of $3.41 \%$ (Table 2 ).

The most favorable time for pollen grains collection and pollination was at 8 a.m. (viable pollen grains average at 8 a.m. was 192.38 and at 3 p.m. was 183.03). Empty pollen grains were also accounted (Figure 3B), with significant differences for different collection times: at 8 a.m. there was the smallest amount of empty pollen grains (average 7.02) and the largest at 3 p.m. (average 16, 27). The A8 accession was the best performing with the least amount of empty pollen grains, while A28 and 'Galia' accessions presented the emptiest pollen grains. There was no significant difference for contracted pollen grains (Figure 3C), with the overall average being 0.579 . The percentages of in vitro germinated pollen grains (Figure 3D) showed significant difference and great variability, with A16 accession showing the lowest germination percentage (19.62\%) and A41 accession the largest $(95.62 \%)$. All female flowers from the evaluated accessions were positive according to the stigmatic receptivity test (Figure 3E - F).

Floral and reproductive genetic diversity and variability - The analysis of diversity in floral characteristics was performed in 24 genotypes, 22 Brazilian accessions, a commercial variety and a melon hybrid (Table 2). Highly significant differences in this germplasm were observed for all floral descriptors analyzed. The PL ranged from $8.81 \mathrm{~mm}$ (A3 accession) to $16.31 \mathrm{~mm}$ (A35 accession), with a coefficient of variation of $13.10 \%$ and an average of $13.57 \mathrm{~mm}$. The FW was higher for A5 accession with $33.29 \mathrm{~mm}$ and $\mathrm{A} 3$ accession presented smaller width with $14.06 \mathrm{~mm}$ being the general average of $27.78 \mathrm{~mm}$. The receptacle length ranged from $6.01 \mathrm{~mm}$ for $\mathrm{A} 17$ accession and $4.29 \mathrm{~mm}$ for A3 accession with an average of 5.35 $\mathrm{mm}$. For the BL characteristic, the commercial variety 'Galia' with $4.60 \mathrm{~mm}$ was larger and the A3 accession was shorter with $1.93 \mathrm{~mm}$ and the overall average was $2.78 \mathrm{~mm}$. Regarding the RW, A29 accession was the one with the lowest value of $2.26 \mathrm{~mm}$ and 'Galia' cultivar the highest value with $3.40 \mathrm{~mm}$. Also for FL, 'Galia' cultivar had the highest value $(35.01 \mathrm{~mm})$ and the A42 accession was the shortest $(19.39 \mathrm{~mm})$.

The Ward-MLM double strategy allowed the analysis of genetic diversity in the germplasm under study, using the reproductive parameters together with the average phenotypic scores of CMV resistance at $21^{\text {st }}$ DAI. With this strategy, the germplasm was distributed in seven genetically distinct groups (Table 3 ). The definition of this ideal number of groups was based on the largest increase in the likelihood function, which occurred in number seven with an increase of 23.37 (Figure 4A). In group 1, six accessions were allocated, while in group 7 only the commercial cultivar 'Galia' was associated. The A16 accession was distributed in the same group as the A16 x PIb intervarietal hybrid.

Although floral descriptors play an important role in the distribution of variation by the Ward-MLM multivariate technique, reproductive characteristics related to viability and in vitro germination of pollen grain were that contributed the most to germplasm distribution (Table 4). However, among the reproductive characteristics, the pollen viability evaluated at 3 p.m. was the one that contributed the least to the understanding of the variation. Group 7, represented by 'Galia' cultivar showed lower pollen viability and also the low emission capacity of in vitro pollen tubes of pollen grains.

The shortest genetic distance between groups 1 and 2, followed by groups 5 and 6 (Table 5). On the other hand, the commercial cultivar 'Galia' was far from the other groups, mainly from group 2, represented by six genotypes. The variation distribution graph using the first two canonical variables allowed the visualization of the distances between the groups, with the sum of the 
two canonical variables sufficient to explain $86.53 \%$ of the variation in the analyzed germplasm for floral and reproductive characteristics (Figure 4B).

Qualitative variables related to symptoms caused by CMV make possible to distribute the variation based on virus resistance levels (Table 6). In group 1 all plants were moderately resistant to $\mathrm{CMV}$, while in groups 2,3 and 4 the largest portion of the germplasm was susceptible, representing $37 \%$ of the analyzed germplasm. Only two genotypes, adding groups 5 and 6 , were potentially resistant to CMV.

Male flowering time ranged from early to median, with plants in groups 2 and 5 exclusively of early flowering (Table 6). On the other hand, in groups 1, 6 and 7, the analyzed germplasm presented median male flowering. Female flowering time ranged from early, median and late, differing among plants in all groups except groups 6 and 7, with early and medium female flowering plants, respectively (Table 6).

CMV is an important biotic stress factor, responsible for productivity loss or melon death, affecting the productivity of this crop in Brazil and other producing countries such as Spain, India and China (VARMA and GIRI, 1998). The search and identification of CMVresistant genetic resources for melon improvement is hampered by the wide variation in symptoms, suggesting quantitative control of resistance. The study based on resistance segregation, based on symptom scores, along with genomic characterization, demonstrate that resistance follows the oligogenic inheritance model with gene prospection and QTL indications associated with different resistance levels (DIAZ et al., 2003; GUIU-ARAGONÉS et al., 2014).

In the present study, the weekly evaluation of symptoms (7, 14 and $21 \mathrm{DAI})$ allowed to set the time of $21 \mathrm{DAI}$ as appropriate to evaluate the Brazilian melon accession, for two reasons: (i) Brazilian susceptible melon accessions did not die until 21 DAI and showed symptoms comparable to the susceptible standard (PS) when inoculated with FNY strain, considered too virulent for melon; (ii) the average values of the control symptoms were close to the maximum and minimum values of the numerical scale, consistent with those previously described for these controls in assessments made from 16 to 20 DAI (GUIU-ARAGONÉS et al., 2014). In the first two weeks of symptom assessment there is no normal distribution of scores, which is reflected in the high coefficient of variation.

The formation of five groups of genotypes representing the different levels of resistance by the Scott-Knott grouping at $21 \mathrm{DAI}$, proves that the analyzed population has wide variation in disease resistance levels. At least nine Brazilian accessions, plus the commercial cultivar 'Galia' and the intervarietal hybrid A16 x PIB presented statistically similar resistance to the resistant cultivar PI, with an indication of similarities in CMV resistance genes among themselves, existing potential for selection in this germplasm. On the other hand, accessions A43 and A45, distributed with susceptible cultivar PS, proved their low resistance to viral infection, with characteristic mosaic on all leaves and death of some plants after 21 DAI.

Genomic variation has been used to understand the oligogenic and quantitative nature of resistance found in the CMV/Cucumis melo phytopathosystem. The identification of QTL involved in CMV resistance in melon was performed using molecular markers such single sequence repeat (SSR), SSR associated with the expressed sequences (EST-SSR) and single nucleotide polymorphism (SNP). In these studies, four genomic regions containing QTL were identified, demonstrating that at least three of them are required in the expression of resistant character (GUIU-ARAGONÉS et al., 2014).

The SNP-CAP AI_33-H11 and PS 40-E11 markers have been previously identified (DELEU et al., 2009), mapped in the linking groups GLIII and GLX, respectively, and are located in the franking (AI_33-H11) and internal (PS_40-E11) regions of QTL associated with variation in $\mathrm{CMV}$ resistance levels (GUIU-ARAGONÉS et al., 2014). In the present study, the presence of mutant alleles in these two molecular loci at frequencies above 0.4 indicates the existence of variability in the Brazilian accessions. The large number of heterozygotes in the Brazilian access can be explained by the allogamous nature of melon plants.

In the present study we also used the CmeIF4E marker which is located near the melon $c m v 1$ resistance gene to CMV. The $c m v 1$ gene has a part in CMV resistance in strains obtained by crossing with homozygous accession and PI resistant. It is known that this gene, located on melon chromosome XII, has greater effect on the variation of the symptomatology expression associated to the infection with CMV, combined with minor effects from at least two of the other QTL (GUIU-ARAGONÉS et al., 2014). Some of the Brazilian melon accessions were homozygous for marker alleles similar to PI resistant cultivar and present low average values of symptoms (present in phenotypic groups I and II defined in the present study). This allows us to hypothesize that the major effect gene present in the melon linkage group XII is naturally present in some Brazilian melon accessions. This hypothesis requires future genetic mapping studies to be tested. In fact, Brazilian materials that have this allele in homozygous are part of groups I and II in the present study, which have the lowest average grade of scores/ symptoms. In addition to indicating marker variability related to CMV resistance, these data allow us to choose promising progenitors for CMV resistance studies in Brazilian accessions. 
Variations of the scores given to the symptoms caused by CMV observed in melon accession corroborate the hypothesis that the Brazilian genetic resource of this crop has potential for the production of contrasting strains for the understanding of genomic relationship between melon and CMV, as well as for the genetic improvement of the crop. However, segregation of genes associated with multiple virus resistance hampers melon improvement aiming at resistance fixing in populations agronomically important. More detailed studies are needed to better understand the genetic nature of CMV resistance found in some Brazilian melon accessions.

The Ward-MLM multivariate strategy allowed to verify variability and quantify genetic diversity based on floral, reproductive and CMV resistance descriptors, including quantitative and qualitative descriptors. The selection and establishment of descriptors for the study of phenotypic variation and its inference on genetic diversity by the Ward-MLM strategy have been widely used in various crops and plant groups (CAMPOS et al., 2013; MELO et al., 2015; GONÇALVES et al., 2018). However, this is the first study that uses floral, reproductive and biotic stress resistance data in the joint multivariate analysis. This analysis proved to be necessary because the reproductive and resistance characters are useful for genetic improvement of melon.

In the present study, seven groups were defined and distributed regarding to genetic distance between accessions. The A16 accession was arranged together with the A16 x PIb intervarietal hybrid, indicating reliability in multivariate analysis since the hybrid genotype shares at least half of identical alleles to A16 parent. The use in multivariate analysis in hybrid plants, reflecting the expected clustering according to the progenitors, has also been observed in other plant groups. For example, the species Passiflora sublanceolata (Killip) MacDougal and Passiflora foetida L., together with different hybrid progenies and backcrosses derived from them, all with potential for ornamental cultivar development, were analyzed for floral descriptors by the Ward-MLM technique, also presenting clusters consistent with their expected genetic diversity based on the crosses performed (MELO et al., 2015).

The commercial cultivar 'Galia' presented itself in an isolated group, farther away from the other groups formed by the Ward-MLM multivariate technique, having particularities attributed to selection throughout the intense process of genetic improvement. In this cultivar, the low pollen viability was the main factor for its isolated distribution from the other accessions. However, its high floral length can compensate for this low viability, due to the greater attraction of pollinators, as already reported in melon intervarietal hybrids (KIILL et al., 2016).
Ward-MLM multivariate analysis can be used to define strategies for plant breeding, such as contributing to the selection of promising progenitors (MELO et al., 2015). The distribution of potentially resistant plants in groups 4 and 6 suggests that these two groups may present promising plants for improving plant resistance to CMV. However, hybridization among potentially resistant plants or among plants with low symptom scores induced by artificial inoculation with CMV does not guarantee that resistant progenies will be obtained, given that the widespread segregation of resistance levels, in part because of the quantitative nature of CMV resistance. This fact is reinforced by comparing the average values of artificial inoculation score of the A16 x PI intervarietal hybrids with the averages of their progenitors with high levels of CMV resistance.

The reproductive biology of melon shows wide variability in flowering time, floral diversity as well as reproductive viability. Knowledge of the timing of male and female flower emission is essential for breeding strategies, especially for the obtention of intervarietal hybrids. Melon plants produces male flowers at the beginning of flowering and later also hermaphrodite flowers. Considering the importance of reproductive biology in breeding programs the results obtained in this and other studies contain relevant information for successful pollination work, because it is a plant dependent on biotic pollinating agents to ensure ovum fertilization and thus produce seeds and fruits (FÁTIMA RIBEIRO and SILVA LIMA, 2017; RIBEIRO et al., 2015).

Brazilian accessions with potential CMV resistance characteristics have floral structures corresponding to the general average. On the other hand, the commercial variety Galia presented higher values than the average for flower morphology. According to Nogueira et al. (2015), the higher values related to floral morphology confer environmental advantage for pollination by bees that have greater intensity in the hottest winter and spring hours favoring increased productivity. Therefore, the results of the present study corroborate with this observation.

The A16 accession and 'Galia' cultivar have the same germinative cell responses, presenting vigorous whole pollen grains with high viability, with low germination percentage. However, the best collection time was at 8 am for A16 accession and at 3 pm for the 'Galia' variety. In addition to the importance of pollination time, the best pollen grain germination is mainly associated with relative humidity and temperature, and the best pollen grain germination of many species usually occurs in the early hours of the morning. However, variations may occur depending on the tolerance degree of pollen grain to desiccation. 
Medium composition and $\mathrm{pH}$ are among the factors affecting in vitro germination. Angiosperm pollen grains invariably need a source of carbon, boron and often other nutrients to promote it. The sugar used in the culture medium is intended to provide osmotic balance between pollen and culture medium, and to provide energy to assist the pollen tube development process. Sucrose is the most widely used sugar because it is the main form of photoassimilate transport between source and drain in higher plants (ALVES DOS SANTOS et al., 2016). Thus, pollen viability and stigma receptivity tests contribute to the definition of the best time to conduct artificial crosses, aiming, for example, to obtain cultivars by hybridization between promising progenitors (DAÍ et al., 2006; SOARES, 2008; SOUSA, 2015).

Fertility analysis of pollen grains from progenitors collected in the field is an indispensable preliminary condition for crosses (CHAGAS et al., 2010). Pollen germination percentage and pollen tube growth are very important for species and cultivars whose fertilization is necessary for fruit production, directly affecting yield.
Along with genetic factors, abiotic factors such as air temperature, humidity, chemical spray also affect the qualitative and quantitative parameters of pollen viability and stigmatic receptivity (SORKHEH, 2011). Melon pollen grains lose their viability after anthesis, especially after $7 \mathrm{~h}$ of anthesis. Reduction of pollen grain viability throughout the day was not found to be influenced by collection times at 8 a.m. and 12 p.m. (ABREU et al., 2008).

The diversity in floral structures and reproductive characteristics observed mainly among Brazilian accessions indicate that there may be different mechanisms involved in the reproduction and distribution of variability in melon plant. Knowledge of reproductive potential and its dynamics contribute to the definition of planting interval among accessions aiming hybridization to obtain intervarietal hybrids and also how to choose the best time for conducting artificial pollination.

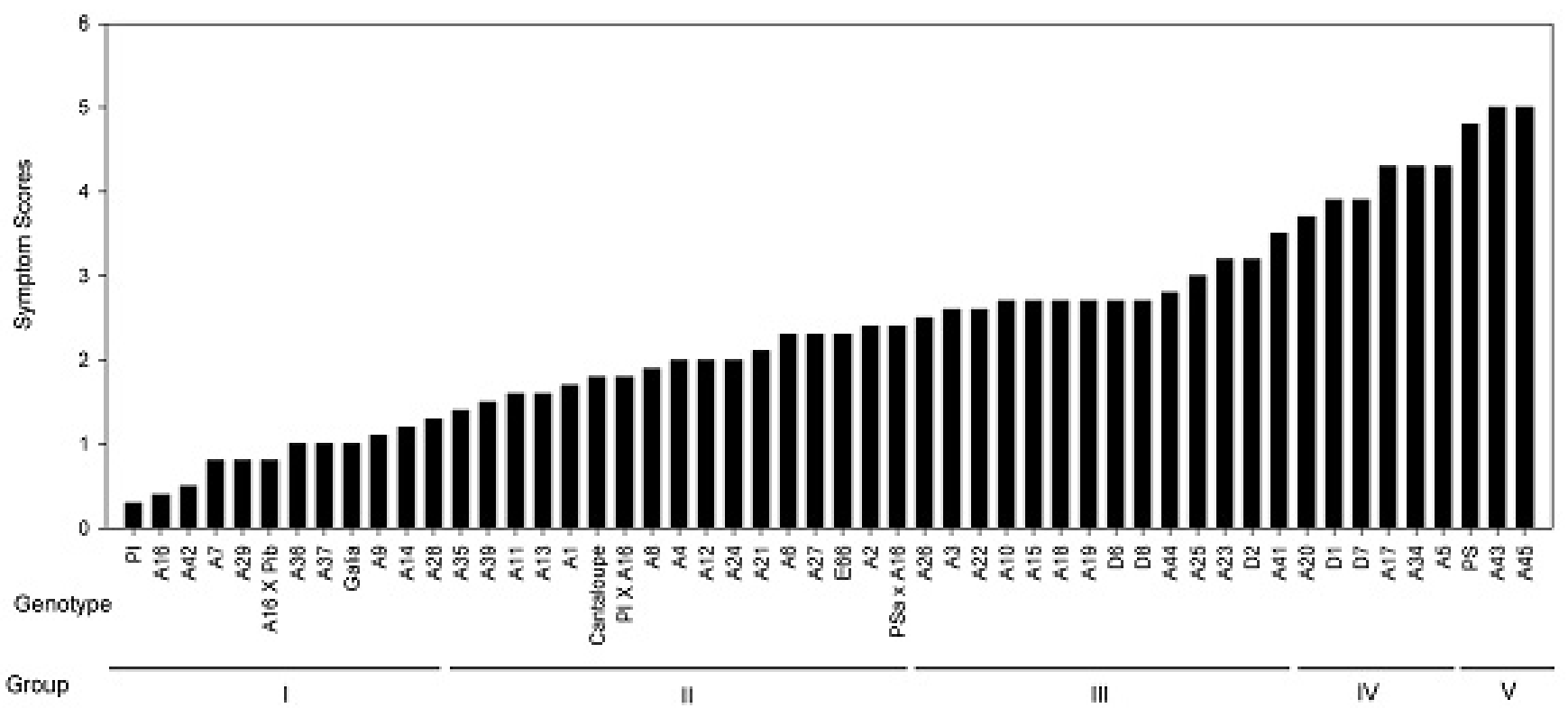

Figure 1. Frequency distribution of symptom scores observed in 52 melon (Cucumis melo) genotypes evaluated at 21 days after artificial inoculation with Cucumber mosaic virus (CMV), indicating the groups (I to V) formed by the Scott- Knott from the middle grades. The genotypes are named as follows: the series identified with A or D, followed by a numeral, are accessions of the germplasm bank; experimental controls are CMV resistant (PI) and susceptible (PS); the others are commercial and hybrid cultivars. 

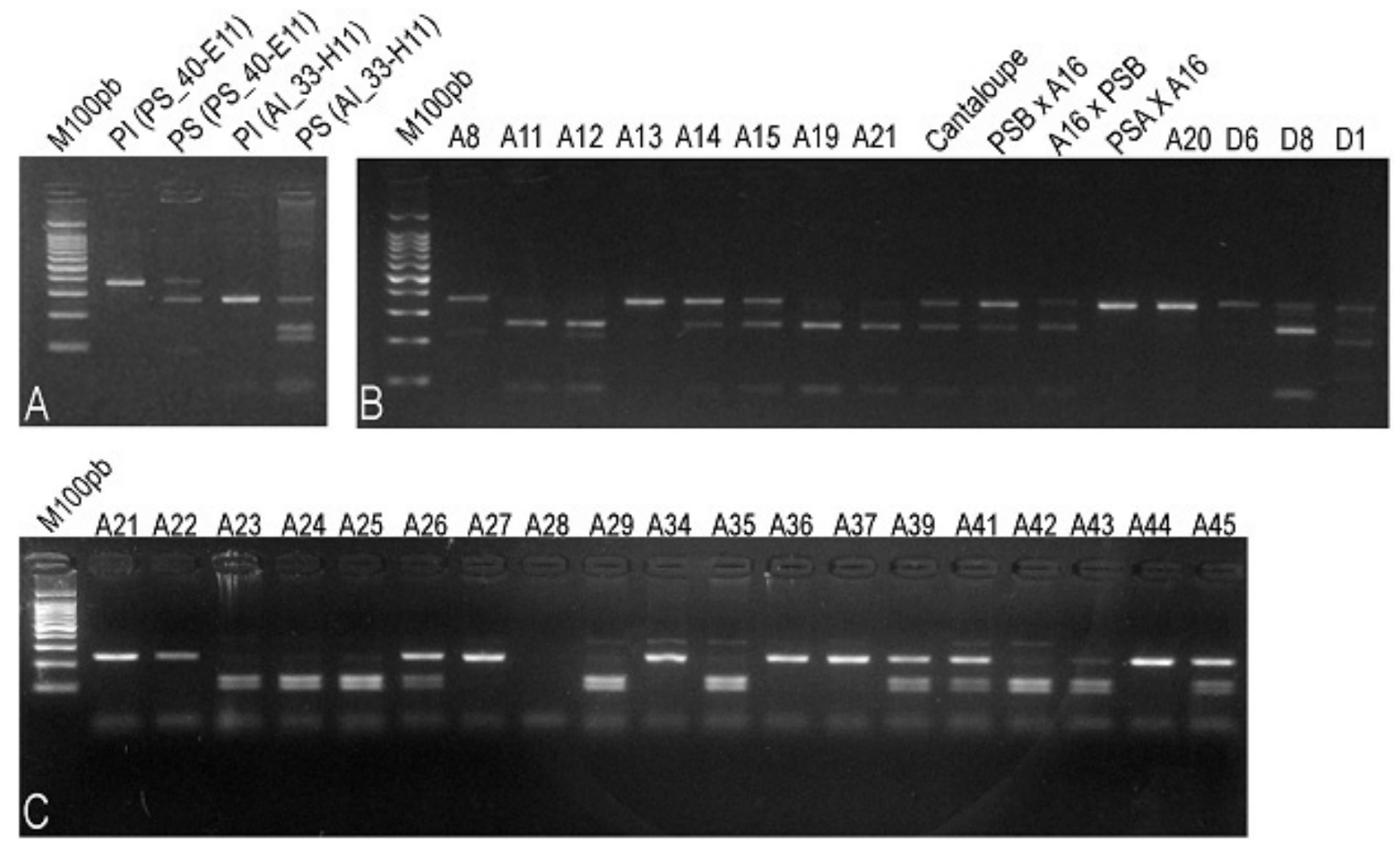

Figure 2. 3\% agarose gel genotyping of a population sample revealing the polymorphism in SNPs-CAPs markers in Brazilian Cucumis melo accessions. A) Genotyped PI and PS accesses for PS_40-E11 and AI_33-H11 loci. B) Genotyped accesses for PS_40-E11 loci. M100bp = 100 bp Ladder molecular weight marker.
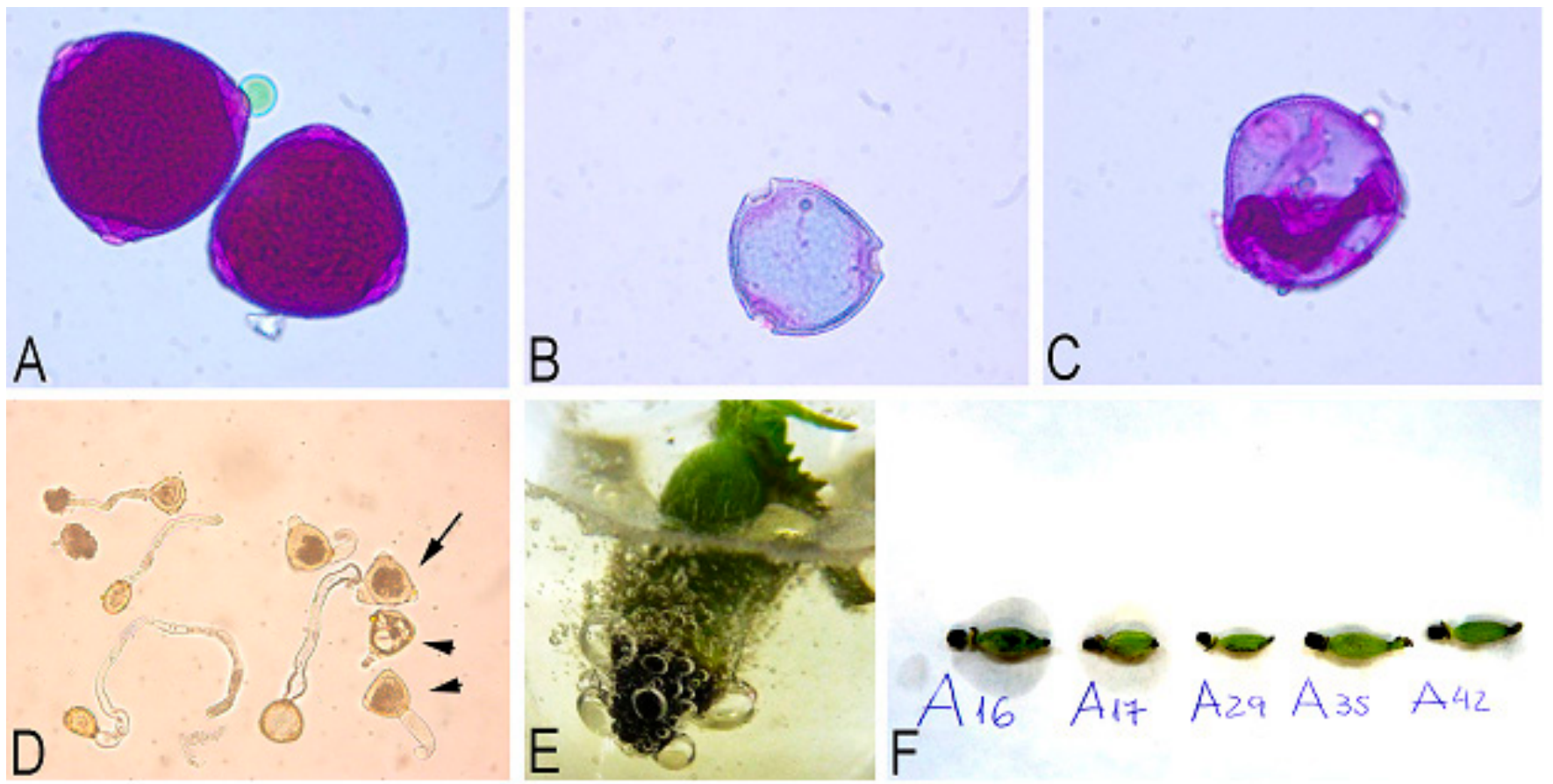

Figure 3. Characteristics of male flower germ cells and receptivity of melon stigma (Cucumis melo). A) Whole pollen grains with viability stained in Alexander; B) Empty pollen grain, not feasible for pollination; C) Collapsed pollen grain considered impracticable for egg fertilization; D) Pollen grains with pollen tube germinated in culture medium, indicating pollen without germinated pollen tube (arrow) and pollen with short pollen tube (arrowhead). E) Stigma receptivity bubbling in benzidine solution and 3\% hydrogen peroxide. F) Black stigmas resulting from oxidation in different Brazilian melon accessions. 
Table 1. Cucumis melo genotypes analyzed and their botanical groups, mean symptom score of symptoms at 21 days after artificial CMV inoculation (DAI), average score grouping by Scott-Knott test and genotypic pattern by SNP-CAP markers loci for CMV QTL resistance.

\begin{tabular}{|c|c|c|c|c|c|}
\hline \multirow{2}{*}{ Genotype } & \multirow{2}{*}{ Botanical group $^{1}$} & \multirow{2}{*}{$\begin{array}{c}\text { Symptom } \\
\text { score }\end{array}$} & \multicolumn{3}{|c|}{ QTL SNP-CAP CMV Resistance } \\
\hline & & & PS_40-E11 & AI_33-H11 & CmeIF4E \\
\hline $\mathrm{A} 1$ & Cantaloupensis & 1.7 & $\mathrm{ab}$ & $\mathrm{ab}$ & $\mathrm{bb}$ \\
\hline $\mathrm{A} 2$ & Cantaloupensis & 2.4 & $\mathrm{bb}$ & $\mathrm{ab}$ & aa \\
\hline $\mathrm{A} 3$ & Cantaloupensis & 2.6 & $\mathrm{ab}$ & $\mathrm{bb}$ & aa \\
\hline A4 & Cantaloupensis & 2.0 & $\mathrm{bb}$ & $\mathrm{bb}$ & aa \\
\hline A5 & $N / D$ & 4.3 & $\mathrm{ab}$ & aa & aa \\
\hline A6 & Cantaloupensis & 2.3 & $\mathrm{bb}$ & $\mathrm{bb}$ & $\mathrm{ab}$ \\
\hline A7 & Cantaloupensis & 0.8 & $\mathrm{bb}$ & $\mathrm{bb}$ & $a b$ \\
\hline A8 & $N / D$ & 1.9 & $\mathrm{ab}$ & $\mathrm{bb}$ & aa \\
\hline A9 & Conomon & 1.1 & $\mathrm{ab}$ & aa & aa \\
\hline A10 & Cantaloupensis & 2.7 & $a b$ & $\mathrm{bb}$ & aa \\
\hline A11 & Conomon & 1.6 & aa & aa & $a b$ \\
\hline A 12 & $N / D$ & 2.0 & aa & $a b$ & aa \\
\hline A13 & Cantaloupensis & 1.6 & $a b$ & $a b$ & $\mathrm{bb}$ \\
\hline A 14 & Cantaloupensis & 1.2 & $a b$ & aa & aa \\
\hline A 15 & Momordica & 2.7 & $a b$ & $a b$ & aa \\
\hline A16 & Conomon & 0.4 & $\mathrm{ab}$ & $a b$ & $\mathrm{bb}$ \\
\hline A17 & Conomon & 4.3 & $a b$ & $a b$ & $a b$ \\
\hline A18 & Cantaloupensis & 2.7 & $\mathrm{ab}$ & $\mathrm{ab}$ & $\mathrm{ab}$ \\
\hline A19 & $N / D$ & 2.7 & aa & aa & $\mathrm{ab}$ \\
\hline A20 & Momordica & 3.7 & $\mathrm{bb}$ & $\mathrm{ab}$ & - \\
\hline A 21 & Conomon & 2.1 & aa & $\mathrm{bb}$ & aa \\
\hline $\mathrm{A} 22$ & Cantaloupensis & 2.6 & $a b$ & $\mathrm{ab}$ & aa \\
\hline $\mathrm{A} 23$ & Momordica & 3.2 & $a b$ & aa & aa \\
\hline A24 & Cantaloupensis & 2.0 & $\mathrm{bb}$ & aa & aa \\
\hline A 25 & Cantaloupensis & 3.0 & $\mathrm{bb}$ & aa & aa \\
\hline A26 & $N / D$ & 2.5 & $a b$ & $a b$ & aa \\
\hline $\mathrm{A} 27$ & $N / D$ & 2.3 & $\mathrm{bb}$ & $\mathrm{bb}$ & aa \\
\hline A28 & Cantaloupensis & 1.3 & aa & $\mathrm{ab}$ & aa \\
\hline A29 & Cantaloupensis & 0.8 & $\mathrm{ab}$ & aa & aa \\
\hline A 34 & Cantaloupensis & 4.3 & $a b$ & $\mathrm{ab}$ & $\mathrm{ab}$ \\
\hline A 35 & $N / D$ & 1.4 & $\mathrm{ab}$ & aa & aa \\
\hline A 36 & Cantaloupensis & 1.0 & $\mathrm{ab}$ & $\mathrm{bb}$ & aa \\
\hline A 37 & Momordica & 1.0 & $\mathrm{bb}$ & $\mathrm{bb}$ & $\mathrm{bb}$ \\
\hline A 39 & Cantaloupensis & 1.5 & $a b$ & $\mathrm{ab}$ & $\mathrm{bb}$ \\
\hline A41 & Cantaloupensis & 3.5 & $a b$ & $\mathrm{ab}$ & $\mathrm{ab}$ \\
\hline A42 & Momordica & 0.5 & $a b$ & aa & $a b$ \\
\hline A43 & Inodorus & 5.0 & $a b$ & aa & aa \\
\hline A44 & Inodorus & 2.8 & $a b$ & $a b$ & aa \\
\hline A45 & Inodorus & 5.0 & $a b$ & aa & aa \\
\hline D1 & $\mathrm{N} / \mathrm{D}$ & 3.9 & $a b$ & aa & $a b$ \\
\hline D2 & N/D & 3.2 & - & - & - \\
\hline D6 & N/D & 2.7 & $\mathrm{bb}$ & $\mathrm{bb}$ & aa \\
\hline D7 & N/D & 3.9 & $\mathrm{bb}$ & $\mathrm{ab}$ & aa \\
\hline D8 & N/D & 2.7 & $\mathrm{ab}$ & $\mathrm{bb}$ & $\mathrm{ab}$ \\
\hline $\mathrm{PI}^{2}$ & Chinensis & 0.3 & $\mathrm{bb}$ & $\mathrm{bb}$ & $\mathrm{bb}$ \\
\hline $\mathrm{PS}^{2}$ & Inodorus & 4.8 & $\mathrm{ab}$ & $\mathrm{ab}$ & aa \\
\hline Galia $^{3}$ & Inodorus & 1.0 & $\mathrm{bb}$ & $\mathrm{bb}$ & $\mathrm{bb}$ \\
\hline Cantaloupe $^{3}$ & Cantaloupensis & 1.8 & $a b$ & $\mathrm{bb}$ & $\mathrm{bb}$ \\
\hline $\mathrm{PSa} \times \mathrm{A} 16^{4}$ & N/D & 2.4 & $\mathrm{bb}$ & $\mathrm{bb}$ & $a b$ \\
\hline $\mathrm{A} 16 \times \mathrm{PIb}^{4}$ & $\mathrm{~N} / \mathrm{D}$ & 0.8 & $a b$ & $a b$ & $a b$ \\
\hline PI X A $16^{4}$ & $\mathrm{~N} / \mathrm{D}$ & 1.8 & $\mathrm{bb}$ & $a b$ & $a b$ \\
\hline E66 & Inodorus & 2.3 & - & - & - \\
\hline
\end{tabular}



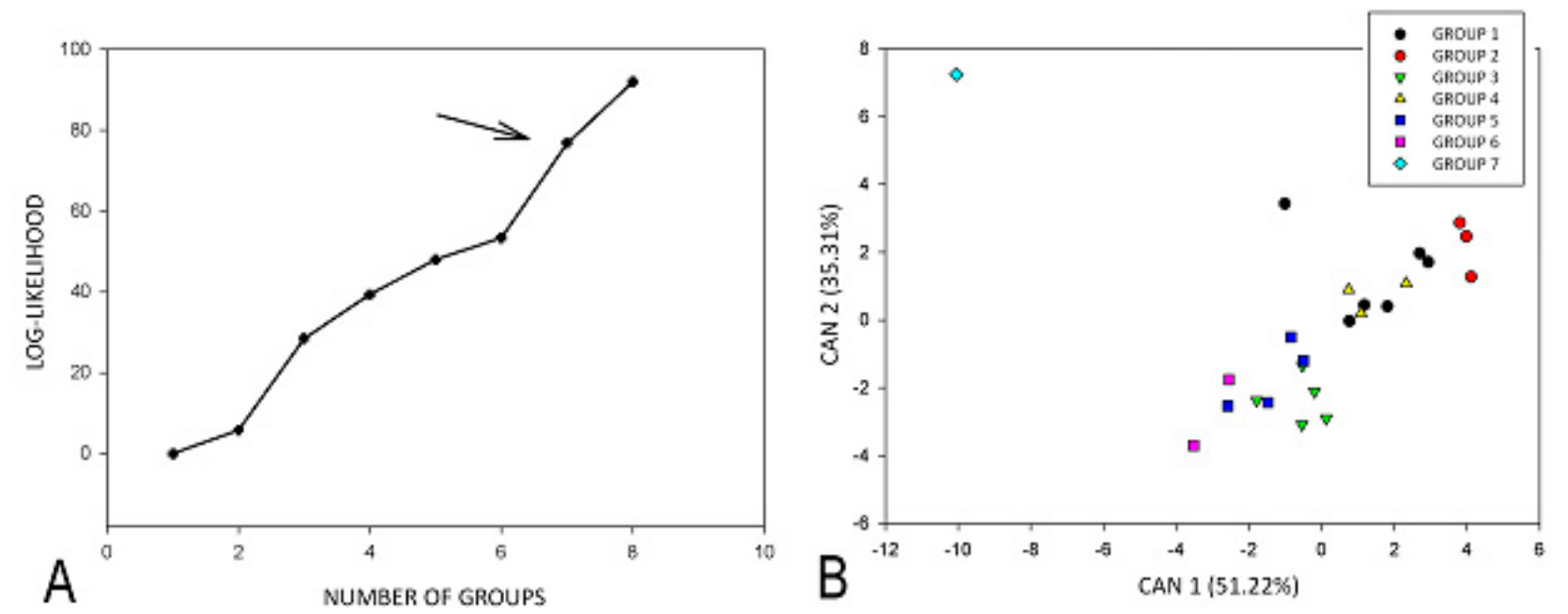

Figure 4. Grouping of 24 genotypes of melon (Cucumis melo) based on quantitative CMV resistance and floral characteristics. A) Definition of the number of groups by the log-likelihood function (Log-Likelihood), forming seven groups (arrow) by the Ward-MLM multivariate strategy. B) Distribution of $86.53 \%$ of the variation with the use of the first two canonical variables in the melon germplasm analyzed.

Table 2. Average values for the floral descriptors and viability and reproductive pollen germination in different genotypes of Cucumis melo.

\begin{tabular}{|c|c|c|c|c|c|c|c|c|c|}
\hline \multirow[b]{2}{*}{ Genotype } & \multicolumn{9}{|c|}{ Descriptor * } \\
\hline & PL & FW & RL & BL & RW & FL & PVM & PVA & PGG \\
\hline $\mathrm{A} 2$ & $13.44 \mathrm{~b}$ & $28.69 \mathrm{c}$ & $5.17 \mathrm{a}$ & $2.10 \mathrm{a}$ & $2.67 \mathrm{a}$ & $25.57 b$ & $194.33 \mathrm{c}$ & $198.16 \mathrm{c}$ & $68.87 \mathrm{e}$ \\
\hline $\mathrm{A} 3$ & $8.81 \mathrm{a}$ & $14.06 \mathrm{a}$ & $4.29 \mathrm{a}$ & $1.93 a$ & $2.47 \mathrm{a}$ & $20.33 a$ & $196.00 \mathrm{c}$ & $195.16 \mathrm{c}$ & $65.00 \mathrm{e}$ \\
\hline A4 & $14.80 \mathrm{~b}$ & $29.29 \mathrm{c}$ & $5.58 \mathrm{~b}$ & $3.07 \mathrm{c}$ & $3.08 \mathrm{~b}$ & $26.11 \mathrm{~b}$ & $197.66 \mathrm{c}$ & $198.16 \mathrm{c}$ & $92.12 \mathrm{~h}$ \\
\hline A5 & $16.21 \mathrm{~b}$ & $33.29 \mathrm{c}$ & $5.12 \mathrm{a}$ & $2.52 b$ & $2.94 \mathrm{~b}$ & $28.55 \mathrm{c}$ & $192.00 \mathrm{c}$ & $192.33 \mathrm{c}$ & $84.50 \mathrm{~g}$ \\
\hline A8 & $14.92 b$ & $30.59 \mathrm{c}$ & $5.89 \mathrm{~b}$ & $3.74 \mathrm{c}$ & $3.14 \mathrm{~b}$ & $30.27 \mathrm{c}$ & $199.33 \mathrm{c}$ & $199.33 \mathrm{c}$ & $86.00 \mathrm{~g}$ \\
\hline A13 & $15.28 \mathrm{~b}$ & $29.44 \mathrm{c}$ & $5.57 \mathrm{~b}$ & $2.77 \mathrm{~b}$ & $3.30 \mathrm{~b}$ & $25.85 b$ & $194.25 \mathrm{c}$ & $193.50 \mathrm{c}$ & $59.75 d$ \\
\hline A14 & $12.34 \mathrm{a}$ & $25.67 \mathrm{~b}$ & $5.44 \mathrm{~b}$ & $2.79 b$ & $2.97 \mathrm{~b}$ & $25.00 \mathrm{~b}$ & $195.16 \mathrm{c}$ & $192.83 \mathrm{c}$ & $78.75 f$ \\
\hline A15 & $12.34 \mathrm{a}$ & $26.27 b$ & $4.87 \mathrm{a}$ & $2.31 \mathrm{a}$ & $2.46 a$ & $24.40 \mathrm{~b}$ & $198.75 \mathrm{c}$ & $198.33 \mathrm{c}$ & $75.75 f$ \\
\hline A16 & $11.62 \mathrm{a}$ & $23.35 b$ & $5.42 b$ & $3.08 \mathrm{c}$ & $3.17 \mathrm{~b}$ & $20.54 \mathrm{a}$ & $193.50 \mathrm{c}$ & $192.16 \mathrm{c}$ & $19.62 \mathrm{a}$ \\
\hline A17 & $15.73 b$ & $31.26 \mathrm{c}$ & $6.01 \mathrm{~b}$ & $2.88 \mathrm{~b}$ & $3.05 \mathrm{~b}$ & $26.68 \mathrm{~b}$ & $192.58 \mathrm{c}$ & $191.33 \mathrm{c}$ & $84.37 \mathrm{~g}$ \\
\hline A22 & $15.52 b$ & $28.89 \mathrm{c}$ & $5.78 b$ & $2.55 \mathrm{~b}$ & $3.10 \mathrm{~b}$ & $27.40 \mathrm{~b}$ & $197.50 \mathrm{c}$ & $197.83 \mathrm{c}$ & $85.37 \mathrm{~g}$ \\
\hline A 25 & $14.47 b$ & $28.42 \mathrm{c}$ & $5.40 \mathrm{~b}$ & $3.38 \mathrm{c}$ & $3.14 \mathrm{~b}$ & $29.12 \mathrm{c}$ & $185.83 \mathrm{c}$ & $191.16 \mathrm{c}$ & $79.00 \mathrm{f}$ \\
\hline A26 & $13.05 \mathrm{a}$ & $27.93 \mathrm{c}$ & $5.92 b$ & $2.46 \mathrm{~b}$ & $3.03 \mathrm{~b}$ & $26.31 \mathrm{~b}$ & $195.50 \mathrm{c}$ & $196.83 \mathrm{c}$ & $62.00 \mathrm{~d}$ \\
\hline A 28 & $13.47 \mathrm{~b}$ & $29.13 c$ & $4.97 \mathrm{a}$ & $2.57 \mathrm{~b}$ & $2.82 \mathrm{~b}$ & $29.40 \mathrm{c}$ & $117.00 \mathrm{a}$ & $38.83 \mathrm{a}$ & $73.00 \mathrm{e}$ \\
\hline A29 & $11.78 \mathrm{a}$ & $24.86 \mathrm{~b}$ & $4.83 a$ & $2.45 \mathrm{~b}$ & $2.26 \mathrm{a}$ & $25.00 \mathrm{~b}$ & $196.66 \mathrm{c}$ & $196.83 \mathrm{c}$ & $71.12 \mathrm{e}$ \\
\hline A35 & $16.31 \mathrm{~b}$ & $32.57 \mathrm{c}$ & $5.06 \mathrm{a}$ & $2.89 \mathrm{~b}$ & $2.94 \mathrm{~b}$ & $28.35 \mathrm{c}$ & $188.83 \mathrm{c}$ & $194.83 \mathrm{c}$ & $27.87 \mathrm{~b}$ \\
\hline A36 & $14.37 \mathrm{~b}$ & $30.12 \mathrm{c}$ & $5.85 \mathrm{~b}$ & $3.31 \mathrm{c}$ & $3.15 \mathrm{~b}$ & $27.02 \mathrm{~b}$ & $197.41 \mathrm{c}$ & $196.50 \mathrm{c}$ & $95.12 \mathrm{~h}$ \\
\hline A37 & $10.92 \mathrm{a}$ & $23.38 b$ & $4.75 \mathrm{a}$ & $2.25 \mathrm{a}$ & $2.90 \mathrm{~b}$ & $20.93 a$ & $137.16 \mathrm{~b}$ & $77.50 \mathrm{~b}$ & $77.87 f$ \\
\hline A39 & $10.32 \mathrm{a}$ & $22.01 \mathrm{~b}$ & $5.11 \mathrm{a}$ & $2.22 \mathrm{a}$ & $2.94 \mathrm{~b}$ & $21.78 \mathrm{a}$ & $194.33 \mathrm{c}$ & $194.50 \mathrm{c}$ & $33.12 b$ \\
\hline A41 & $15.81 \mathrm{~b}$ & $32.76 \mathrm{c}$ & $6.11 \mathrm{~b}$ & $3.68 \mathrm{c}$ & $3.11 \mathrm{~b}$ & $30.53 c$ & $195.91 \mathrm{c}$ & $195.33 \mathrm{c}$ & $95.62 \mathrm{~h}$ \\
\hline $\mathrm{A} 42$ & $10.80 \mathrm{a}$ & $22.92 b$ & $5.03 a$ & $1.68 \mathrm{a}$ & $2.54 \mathrm{a}$ & $19.39 \mathrm{a}$ & $195.00 \mathrm{c}$ & $194.16 \mathrm{c}$ & $95.12 \mathrm{~h}$ \\
\hline $\mathrm{A} 45$ & $15.43 b$ & $32.44 \mathrm{c}$ & $5.25 \mathrm{~b}$ & $2.78 \mathrm{~b}$ & $2.98 \mathrm{~b}$ & $26.48 b$ & $187.83 \mathrm{c}$ & $183.33 \mathrm{c}$ & $93.62 \mathrm{~h}$ \\
\hline Gália & $15.44 b$ & $32.44 \mathrm{c}$ & $5.48 \mathrm{~b}$ & $4.6 \mathrm{c}$ & $3.40 \mathrm{~b}$ & $35.01 \mathrm{c}$ & $169.25 \mathrm{c}$ & $193.50 \mathrm{c}$ & $53.75 \mathrm{c}$ \\
\hline $\mathrm{A} 16 \times \mathrm{PIb}$ & $12.49 \mathrm{a}$ & $26.87 \mathrm{~b}$ & $5.49 \mathrm{~b}$ & $2.63 \mathrm{~b}$ & $3.20 \mathrm{~b}$ & $27.60 \mathrm{~b}$ & $193.83 \mathrm{c}$ & $191.50 \mathrm{c}$ & $50.50 \mathrm{c}$ \\
\hline CV\% & 13.10 & 12.15 & 8.69 & 16.46 & 10.17 & 11.80 & 11.64 & 3.41 & 7.44 \\
\hline Mean & 13.57 & 27.78 & 5.35 & 2.78 & 2.95 & 26.15 & 187.73 & 183.08 & 71.16 \\
\hline
\end{tabular}

* PL petal length, FW flower width, RL receptacle length, BL bracts length, RW receptacle width, FL flower length, PVM pollen grain viability at $8 \mathrm{~h}$ a.m, PVA pollen grain viability at $3 \mathrm{~h}$ p.m. PGG pollen grain germination, CV\% coefficient and variation . Means followed by the same letters in the columns do not differ statistically by the Scott-Knott test at $5 \%$ probability. Genotypes identified with the letter A followed by numbers are accessions of the germplasm bank; 'Galia' is a commercial cultivar A16 x PIb is a hybrid. 
Table 3. Groups of melon (Cucumis melo) formed by the Ward-MLM methods by the analysis of quantitative data.

\begin{tabular}{llc}
\hline Group & \multicolumn{1}{c}{ Genotype } & Main feature * \\
\hline $\mathbf{1}$ & A4; A13; A14; A25; A28; A36 & Most accesses \\
$\mathbf{2}$ & A8; A22; A41 & Highest averages of RL \\
$\mathbf{3}$ & A2; A3; A15; A26; A29 & Lowest average of RL \\
$\mathbf{4}$ & A5; A17; A45 & Highest averages of PL \\
$\mathbf{5}$ & A16; A37; A42; A16 x PIb & Lowest means for PL \\
$\mathbf{6}$ & A35; A39 & - \\
$\mathbf{7}$ & Gália & Commercial cultivar only \\
\hline
\end{tabular}

*PL Petal length, RL receptacle length.

Table 4. Means of the quantitative floral descriptors and in vitro viability and germination of melon pollen grain (Cucumis melo) for each of the seven groups formed by the Ward-MLM method and the first two canonical variables $(\mathrm{CAN})$.

\begin{tabular}{|c|c|c|c|c|c|c|c|c|c|}
\hline \multirow{2}{*}{ Descriptor } & \multicolumn{7}{|c|}{ Group } & \multicolumn{2}{|c|}{ Canonical Variable } \\
\hline & $1(6)$ & $2(3)$ & $3(5)$ & $4(3)$ & $5(4)$ & $6(2)$ & $7(1)$ & CAN1 & CAN2 \\
\hline PL & 14.14 & 15.41 & 11.89 & 15.79 & 11.46 & 13.32 & 15.44 & 0.2598 & 0.6407 \\
\hline FW & 28.68 & 30.75 & 24.36 & 32.33 & 24.14 & 27.29 & 32.44 & 0.1672 & 0.5935 \\
\hline RL & 5.47 & 5.92 & 5.01 & 5.46 & 5.17 & 5.09 & 5.49 & $0.3624 *$ & 0.5345 \\
\hline BL & 2.99 & 3.33 & 2.25 & 2.73 & 2.41 & 2.55 & 4.61 & 0.1321 & 0.8453 \\
\hline RW & 3.08 & 3.12 & 2.58 & 2.99 & 2.95 & 2.94 & 3.41 & $0.0115^{* *}$ & 0.6742 \\
\hline FW & 27.08 & 29.40 & 24.36 & 27.23 & 22.11 & 25.07 & 35.01 & -0.0184 & 0.7798 \\
\hline PVM & 96.97 & 98.83 & 97.71 & 96.30 & 97.96 & 94.25 & 72.50 & $0.7767 *$ & -0.5795 \\
\hline PVA & 84.25 & 98.75 & 98.53 & 94.50 & 81.91 & 97.33 & 96.75 & $0.0152 * *$ & -0.0157 \\
\hline PG & 79.62 & 89.00 & 68.55 & 87.50 & 60.78 & 30.50 & 53.75 & 0.6095 & 0.3721 \\
\hline
\end{tabular}

*PL) petals length; FW) flower width; RL) receptacle length; BL) bracts length, RW) receptacle width; FL) flower length; PVM) Pollen viability at 8 h a.m; PVA) Pollen viability at 15 h.p m PG) Pollen germination. CAN1) canonical variable 1; CAN2) canonical variable $2 .{ }^{*}$ descriptor with greatest .contribution to distribution in variation in the first canonical variable; $* *$ descriptor with minor contribution to distribution in variation in the first canonical variable.

Table 5. Genetic distance between the Ward-MLM groups verified in different accessions of Cucumis melo using quantitative and qualitative floral and reproductive information.

\begin{tabular}{cccccccc}
\hline Group & $\mathbf{1}$ & $\mathbf{2}$ & $\mathbf{3}$ & $\mathbf{4}$ & $\mathbf{5}$ & $\mathbf{6}$ & $\mathbf{7}$ \\
\hline $\mathbf{1}$ & 0 & 10.28 & 22.73 & 3.92 & 18.28 & 39.15 & 168.58 \\
$\mathbf{2}$ & & 0 & 42.92 & 16.21 & 50.99 & 77.18 & 222.38 \\
$\mathbf{3}$ & & & 0 & 21.74 & 12.77 & 13.55 & 182.47 \\
$\mathbf{4}$ & & & & 0 & 19.36 & 35.43 & 178.69 \\
$\mathbf{5}$ & & & & & 0 & 11.20 & 162.52 \\
$\mathbf{6}$ & & & & & & 0 & 153.19 \\
$\mathbf{7}$ & & & & & & & 0 \\
\hline
\end{tabular}


Table 6. Distribution of qualitative characteristics analyzed in the Ward-MLM multivariate strategy. Absolute frequency of variation in resistance levels of Cucumis melo to Cucumber mosaic virus (CMV) in each of the seven groups formed. Frequency in the male and female flowering stage. Values indicate the number of plants in each group with the resistance level evaluated.

\begin{tabular}{|c|c|c|c|c|c|c|c|c|}
\hline \multirow{2}{*}{\multicolumn{2}{|c|}{ Qualitative characteristic }} & \multicolumn{7}{|c|}{ Group } \\
\hline & & $1(6)$ & 2(3) & $3(5)$ & $4(3)$ & $5(4)$ & $6(2)$ & $7(1)$ \\
\hline \multirow{3}{*}{ 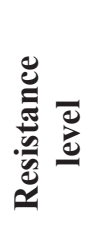 } & Susceptible & - & 2 & 4 & 3 & - & - & - \\
\hline & Moderately resistant & 6 & 1 & 1 & - & 3 & 1 & 1 \\
\hline & Potentially resistant & - & - & - & - & 1 & 1 & - \\
\hline \multirow{3}{*}{ 芴 } & Premature & - & 3 & 1 & 2 & 4 & - & - \\
\hline & Median & 6 & - & 4 & 1 & - & 2 & 1 \\
\hline & Late & - & - & - & - & - & - & - \\
\hline \multirow{3}{*}{ 资 } & Premature & - & 1 & 1 & - & 1 & 2 & - \\
\hline & Median & 3 & 1 & 4 & 2 & 3 & - & 1 \\
\hline & Late & 3 & 1 & - & 1 & - & - & - \\
\hline
\end{tabular}

\section{Conclusions}

Melon accessions available in the Brazilian germplasm bank have variability in the resistance levels to CMV (FNY strain). These accessions present polymorphism in resistance marker loci located in the main QTL previously associated with melon resistance to CMV. There is genetic diversity regarding resistance to CMV and to the descriptors of floral morphology and reproductive behavior available for using in melon genetic improvement and in the studies of molecular mechanisms involved in determining these characteristics.

\section{Acknowledgements}

The authors would like to thank the Active Bank of Cucurbitaceae Germplasm of the Federal University of Semiarid (UFERSA), for the concession of the seeds. To the Center for Research in Agricultural Genomics (CRAG) for the technical instructions on phytopathological tests of the melon-CMV pathosystem. We also thank to the Coordination for the Improvement of Higher Education Personnel (CAPES) for financing Project 184, request no. 2628/2013 and granting the scholarship to the first and second authors and to the National Council for Scientific and Technological Development (CNPq), for granting the scientific productivity scholarship to the last author.

\section{References}

ABREU, T.B.; NUNES, G.D.S.; DANTAS, M.S.M.; DA COSTA FILHO, J.H.; COSTA, G.G. DE ARAGÃO, F.A.S. Fenologia floral, viabilidade do grão de pólen e receptividade do estigma do meloeiro. Proceedings of the Interamerican Society for Tropical Horticulture, San José, v.52, p.43-46, 2008.

ALVES-DOS-SANTOS, I.; SILVA, C.I. da; PINHEIRO, M.; KLEINERT, A de M.P. Quando um visitante floral é um polinizador? Rodriguésia, Rio de Janeiro, v.67, n.2, p.295-307, 2016.

ARAGÃO, F.A.S., TORRES FILHO, J., NUNES, G.H.S., QUEIRÓZ, M.A., BORDALLO, P.N., BUSO, G.S.C., FERREIRA NETO, F. Genetic divergence among accessions of melon from traditional agriculture of the Brazilian Northeast. Genetics and Molecular Research, Ribeirão Preto, v.12, n.4, p.6356-6371, 2013.

BRUCKNER, C.H.; SILVA, M.M.; FALLEIRO, T.M.; ANDRADE, B.B.; MOREIRA, A.E. Viabilidade do pólen de maracujazeiro sob diferentes condições de armazenamento. Revista Ceres, Viçosa, MG, v.47, p.523$531,2000$. 
CAMPOS, B.M.; VIANA, A.P.; QUINTAL, S.S.R.; GONÇALVES, L.S.A.; PESSANHA, P.G.O. de. Quantificação da divergência genética entre acessos de goibeira por meio da estratégia Ward-MLM. Revista Brasileira de Fruticultura, Jaboticabal, v.35, n.2, p.571$578,2013$.

CASTILHOS, L.F. Cultivo de melão e melancia. Curitiba: Tecpar, 2012.

CASTRO LIMA, E.M. de; AMARAL FARIA, L. do; CUNHA SIQUEIRA, W. da; REZENDE, F.C.; GOMES, L.A.A.; CUSTODIO, T.N. Crescimento e Produção de Melão Cultivado Em Ambiente Protegido e Irrigado Por Gotejamento. Irriga, Botucatu, v.14, n.4, p.449-457, 2018.

CHAGAS, E.A.; PIO, R.; CHAGAS, P.C.; PASQUAL, M.; BETIOL NETO, J.E. Composição do meio de cultura e condições ambientais para germinação de grãos de pólen de porta-enxertos de pereira. Ciência Rural, Santa Maria, v.40, n.2, p.261-266, 2010.

CORRÊA, R.X.; ABDELNOOR, R.V.; FALEIRO, F.G.; MOREIRA, M.A.; BARROS, E.G. Genetic distances in soybean based on RAPD markers. Bragantia, Campinas, v.58, n.1, p.15-22, 1999.

COSTA, N.D. (ed.). Sistema de produção de melão. Petrolina: Embrapa Semiárido, 2012. (Sistemas de Produção, 5)

DAI, S.; LI, L.; CHEN, T.; CHONG, K.; XUE, Y. WANG, T. Proteomic analyses of Oryza sativa mature pollen reveal novel proteins associated with pollen germination and tube growth. Molecular \& Cellular Proteomics, Bethesda, v.6, n.8, p.2504-2529, 2006.

DANTAS, A.C.D.A.; NUNES, G.H.S.; ARAÚJO, I.S.; ALBUQUERQUE, L.B.A. Caracterização molecular de acessos de melão coletados no Nordeste brasileiro. Revista Brasileira de Fruticultura, Jaboticabal, v.34, n.1, p.183-189, 2012.

DELEU, W.; ESTERAS, C.; ROIG, C.; GONZÁLEZ-TO, M.; FERNÁNDEZ-SILVA, I.; GONZALEZ-IBEAS, D.; MONFORTE, A.J. A set of EST-SNPs for map saturation and cultivar identification in melon. BMC Plant Biology, London, v.9, n.1, p.90, 2009.

DIAZ, J.A.; MALLOR, C.; SORIA, C.; CAMERO, R.; GARZO, E.; FERERES, A.; ALVAREZ, J.M.; GÓMEZ-GUILLAMÓN, M.L.; LUIS-ARTEAGA, M.; MORIONES E. Potential sources of resistance for melon to nonpersistently aphid-borne viruses. Plant Diseases, Pullman, v.87, p.960-964, 2003.
DOYLE, J.J.; DOYLE, J.L. Isolation of plant DNA from fresh tissue. Focus, Boston, v.12, p.13-15. 1990.

DUBEY, V.K.; CHANDRASEKHAR, K.; SRIVASTAVA, A.; AMINUDDIN, SINGH, V.P.; DHAR, K.; ARORA, P.K. Expression of coat protein gene of Cucumber mosaic virus (CMV-subgroup IA) Gladiolus isolate in Nicotiana tabacum. Journal of Plant Interactions, London, v.10, n.1, p.296-304, 2015.

EDUARDO, I.; ARÚS, P.; MONFORTE, A. J. Development of a genomic library of near isogenic lines (NILs) in melon (Cucumis melo L.) from the exotic accession PI161375. Theoretical and Applied Genetics, Berlin, v.112, n.1, p.139-148, 2005. (1)

ESSAFI, A.; DIAZ-PENDON, J.A.; MORIONES, E.; MONFORTE, A.J.; GARCIA-MAS, J.; MARTINHERNANDEZ, A.M. Dissection of the oligogenic resistance to Cucumber mosaic virus in the melon accession PI 161375. Theoretical and Applied Genetics, Berlin, v.118, p.275-284, 2009.

FÁTIMA RIBEIRO, M. de; SILVA LIMA, C.B. da. Avaliação da criação de abelhas-sem-ferrão em Fernando de Noronha após 30 anos de sua introdução. MAGISTRA, Cruz das Almas, v.27, n.3/4, p.474-501, 2017.

FERREIRA, D.F. Sisvar: a computer statistical analysis system. Ciência e Agrotecnologia, Lavras, v.35, n.6, p.1039-1042, 2011.

GINER,A.; PASCUAL, L.; BOURGEOIS, M.; GYETVAI, G.; RIOS, P.; PICÓ, B.; MARTÍN-HERNÁNDEZ, A.M. A mutation in the melon Vacuolar Protein Sorting 41 prevents systemic infection of Cucumber mosaic virus. Scientific Reports, London, v.7, n.1, p.10471, 2017.

GONÇALVES, Z.S.; INVENÇÃO, D.R.S.; LEDO, C.D.S.; FERREIRA, C.F.; AMORIM, E.P. Agronomic performance of plantain genotypes and genetic variability using Ward-MLM algorithm. Genetics and Molecular Research, Ribeirão Preto, v.17, n.1, p.gmr16039882, 2018.

GOWER, J.C. A general coefficient of similarity and some of its properties. Biometrics, Oxford, p.857-871, 1971.

GUIU-ARAGONÉS, C.; MONFORTE, A.J.; SALADIÉ, M.; CORRÊA, R.X.; GARCIA-MAS, J.; MARTÍNHERNÁNDEZ, A.M. The complex resistance to cucumber mosaic cucumo virus (CMV) in the melon accession PI161375 is governed by one gene and at least two quantitative trait loci. Molecular Breeding, Dordrecht, v.34, n.2, p.351-362, 2014. 
KIILL, L.H.P., FEITOZA, E.D.A., SIQUEIRA, K., RIBEIRO, M.D.F., SILVA, E.M.S.D. Evaluation of floral characteristics of melon hybrids (Cucumis melo L.) in pollinator attractiveness. Revista Brasileira de Fruticultura, Jaboticabal, v.38, n.2, e.531, 2016.

LECOQ, H.; COHEN, S.; PITRAT, M.; LABONNE, G. Resistence to Curcumber Mosaic Virus Transmission by Aphids in Cucumis melo. Phytopatology, St Paul, v.69, n.12, p.1223- 1225, 1979.

MELO, C.A.F. SOUZA, M.M.; SOUSA, A.G.R.; VIANA, A.P.; SANTOS, E.A. Multivariate analysis of backcross progeny of Passiflora L.(Passifloraceae) for pre-breeding genotype selection. Genetics and Molecular Research, Ribeirão Preto, v.14, n.4, p.15376-15389, 2015.

MOCHIZUKI, T.; OHKI, S.T. Cucumber mosaic virus: viral genes as virulence determinants. Molecular Plant Pathology, Oxford, v.13, n.3, p.217-225, 2012.

MORENO, E.; OBANDO, J. M.; DOS-SANTOS, N.; FERNÁNDEZ-TRUJILLO, J.P.; MONFORTE, A.J.; GARCIA-MAS, J. Candidate genes and QTLs for fruit ripening and softening in melon. Theoretical and Applied Genetics, Berlin, v.116, n.4, p.589-602, 2008.

MORRONI, M.; THOMPSON, J.R.; TEPFER, M. Twenty years of transgenic plants resistant to Cucumber mosaic virus. Molecular Plant-microbe Interactions, St Paul, v.21, n.6, p.675-684, 2008.

NOGUEIRA, P.V.; SILVA, D.F.; PIO, R.; SILVA, P.A.O.; BISI, R.B.; BALBI, R.V. Germinação de pólen e aplicação de ácido bórico em botões florais de nespereiras. Bragantia, Campinas, v.74, n.1, p.9-15, 2015.

PALUKAITIS, P.; ROOSSINCK, M.J.; DIETZGEN, R.G.; FRANCKI, R.I. Cucumber mosaic virus. Advances in Virus Research, London, v.41, p.281-348, 1992.

RIBEIRO, M.D.F.; SILVA, E.M.S.D.; JÚNIOR, L.; DE OLIVEIRA, I.; KIILL, L.H.P. Honey bees (Apis mellifera) visiting flowers of yellow melon (Cucumis melo) using different number of hives. Ciência Rural, Santa Rural, v.45, n.10, p.1768-1773, 2015.

ROCHA, R.H.C.; SILVA, E.D.O.; SALOMÃO, L.C.C.; VENTRELLA, M.C. Caracterização morfoanatômica do melão gália no ponto de colheita. Revista Brasileira de Fruticultura, Jaboticabal, v.32, n.2, p.375-385, 2010.
SALLES, L.A.; RAMOS, J.D.; PASQUAL, M.; JUNQUEIRA, K.P.; SILVA, A.B. Sacarose e pH na germinação in vitro de grãos de pólen de citros. Ciência e Agrotecnologia, Lavras, v.30, n.1, p.170-174, 2006.

SAMARAKOON, T.; WANG, S.Y.; ALFORD, M.H. Enhancing PCR amplification of DNA from recalcitrant plant specimens using a trehalose based additive. Applications in Plant Sciences, Washington, v.1, n.1, p.1200236, 2013.

SAS INSTITUTE. SAS user's guide: statistic. Cary, 2000.

SOARES, T.L.; SILVA, S.O.; COSTA, M.A.P.C.; SANTOS-SEREJO, J.A.; SOUZA, A.D.S.; LINO, L.S.M.; JESUS, O.N. In vitro germination and viability of pollen grains of banana diploids. Crop Breeding and Applied Biotechnology, Lavras, v.8, n.2, p.111-118, 2008.

SORKHEH, K.; SHIRAN, B.; ROUHI, V.; KHODAMBASHI, M.; WOLUKAU, J.N.; ERCISLI, S. Response of in vitro pollen germination and pollen tube growth of almond (Prunus dulcis Mill.) to temperature, polyamines and polyamine synthesis inhibitor. Biochemical Systematics and Ecology, New York, v.39, p.749-757, 2011.

SOUSA, A.D.S. Viabilidade e ação de lectinas na germinação in vitro de grãos de pólen de dendezeiro (Elaeis guineensis Jacq.-Arecaceae). 2015. Dissertação (Mestrado em Recursos Genéticos Vegetais) - Universidade Federal de Feira de Santana, Feira de Santana, 2015.

SOUSA, R.M.; SOUSA AGUIAR, O.D.; FREITAS, B.M.; SILVEIRA NETO, A.A.D.; FLADNER COSTA PEREIRA, T. Requerimentos de polinização do meloeiro (Cucumis melo L.) no município de Acaraú-CE-Brasil. Revista Caatinga, Mossoró, v.22, n.1, 2009.

STAUB, J.E.; LÓPEZ-SESÉ, A.I.; FANOURAKIS, N. Diversity among melon landraces (Cucumis melo L.) from Greece and their genetic relationships with other melon germplasm of diverse origins. Euphytica, Dordrecht, v.136, n.2, p.151-166, 2004.

STEPANSKY, A.; KOVALSKI, I.; PERL-TREVES, R. Intraspecific classification of melons (Cucumis melo L.) in view of their phenotypic and molecular variation. Plant Systematics and Evolution, Wien, v.217, n.3-4, p.313332, 1999. 
TORRES FILHO, J.; DE SOUSA NUNES, G.H.; VARMA, A.; GIRI, B.K. Virus disease. In: NAYAR, N.M.; VASCONCELOS, J.J.C.; DA COSTA FILHO, J.H.; MORE, T.A. (ed.). Cucurbits. New Delhi: Oxford and COSTA, G.G. Caracterização morfológica de acessos IBH Publishing, 1998. p.225-245.

de meloeiro coletados no nordeste brasileiro. Revista

Caatinga, Mossoró, v.22, n.3, p.174-181, 2009. 